\title{
The Relationship between Mollusks and Oxygen Concentrations in Todos Santos Bay, Baja California, Mexico
}

\author{
J. Gabriel Kuk-Dzul and Victoria Díaz-Castañeda \\ CICESE, Departamento de Ecología, Carretera Ensenada-Tijuana 3918, 22860 Ensenada, BC, Mexico \\ Correspondence should be addressed to Victoria Díaz-Castañeda; vidiaz@cicese.mx
}

Received 30 April 2016; Revised 7 July 2016; Accepted 12 July 2016

Academic Editor: Norman Ying Shiu Woo

Copyright ( 2016 J. G. Kuk-Dzul and V. Díaz-Castañeda. This is an open access article distributed under the Creative Commons Attribution License, which permits unrestricted use, distribution, and reproduction in any medium, provided the original work is properly cited.

\begin{abstract}
This study describes the relationship between mollusks, physicochemical properties of seawater, and sediments under natural conditions of low impact. Thirty-nine stations were sampled in October 1994 using a Van Veen grab $\left(0.1 \mathrm{~m}^{-2}\right)$. Temperature, salinity, and dissolved oxygen (DO) concentrations of bottom water were obtained with a CTD. Organic matter content and sediment grain analysis were determined. A total of 836 mollusks were collected. Gastropoda was the most abundant (52\%) and diverse class with 27 genera, followed by Bivalvia with eight genera and Scaphopoda with only one genus. According to CCA analysis, dominant mollusks were significantly related with high DO concentrations. Donax, Natica, Acteocina, Bulla, Anachis, Odostomia, and Crucibulum can be classified as sensitive genera because they were found mainly in high oxygen concentrations (3.1-5.6 $\mathrm{mL} \mathrm{L}^{-1}$ ); on the other hand, Cardiomya, Nuculana, Laevicardium, Chione, Truncatella, and Dentalium can be classified as tolerant genera $\left(1.0-5.6 \mathrm{~mL} \mathrm{~L}^{-1}\right)$. Todos Santos Bay hosts a diverse malacological fauna (36 genera); our results show that the dominant genera were mainly related to high dissolved oxygen concentrations. Mollusks can be a useful tool in environmental monitoring programs related with oxygen depletion in coastal areas.
\end{abstract}

\section{Introduction}

The phylum Mollusca is the second more diverse in number of species only overcome by the phylum Arthropoda [1]. Mollusks play an important role in the recycling of nutrients; they are important members of food webs as preys and predators [2], some mollusks are exploited commercially by human populations [3-5], and other species are used to get chemical compounds for the pharmaceutical industry [6]. Besides, mollusks have been employed as pollution bioindicators in coastal environments $[7,8]$.

Pollution in the coastal areas is usually related to human activities, for example, discharge of wastewater, agricultural run-off, discharges from desalination plants, and mariculture. Hypoxic and anoxic conditions prevail in some aquatic systems, such as bays, coastal lagoons, or estuaries; however, oxygen depletion has increased in coastal environments since the 1960s [9]. Mariculture and other anthropogenic activities can favor eutrophication in aquatic systems causing oxygen depletion with important ecological consequences.
Todos Santos Bay (TSB) is located in the northwest coast of Baja California, $100 \mathrm{~km}$ from the US-Mexico border at $31^{\circ} 42^{\prime}-31^{\circ} 53^{\prime} \mathrm{N} ; 116^{\circ} 37^{\prime}-116^{\circ} 49^{\prime} \mathrm{W}$. It has an area of approximately $168 \mathrm{~km}^{2}$ [10]; the limits are Punta San Miguel to the north, Punta Banda to the south, and Todos Santos islands to the west (Figure 1). Approximately $80 \%$ of the bay lies between 10 and $50 \mathrm{~m}$ in depth [11,12]; a submarine canyon is located at the southwest entrance of the bay reaching depths of nearly $500 \mathrm{~m}$ [13]. Within TSB the northwestern winds are dominant and variability is due to the high pressure system centered to the west of California. The main direction of superficial current is towards the southeast entering by the mouth. This current reaches up to $\sim 35 \mathrm{~m}$ in depth; in the shallow coast of the bay $(<35 \mathrm{~m})$ the circulation is anticyclonic [14]. Currents are stronger in the southern area and near the mouth and weaker in the north and near the coast [15]. In the southern part aquaculture of mussels Mytilus edulis and oysters Crassostrea gigas takes place since 1991 and 1994, respectively, and from 2000 to 2007 the annual mean production of Crassostrea gigas has been 590 ton $\mathrm{yr}^{-1}$ [16]. Occasionally the 


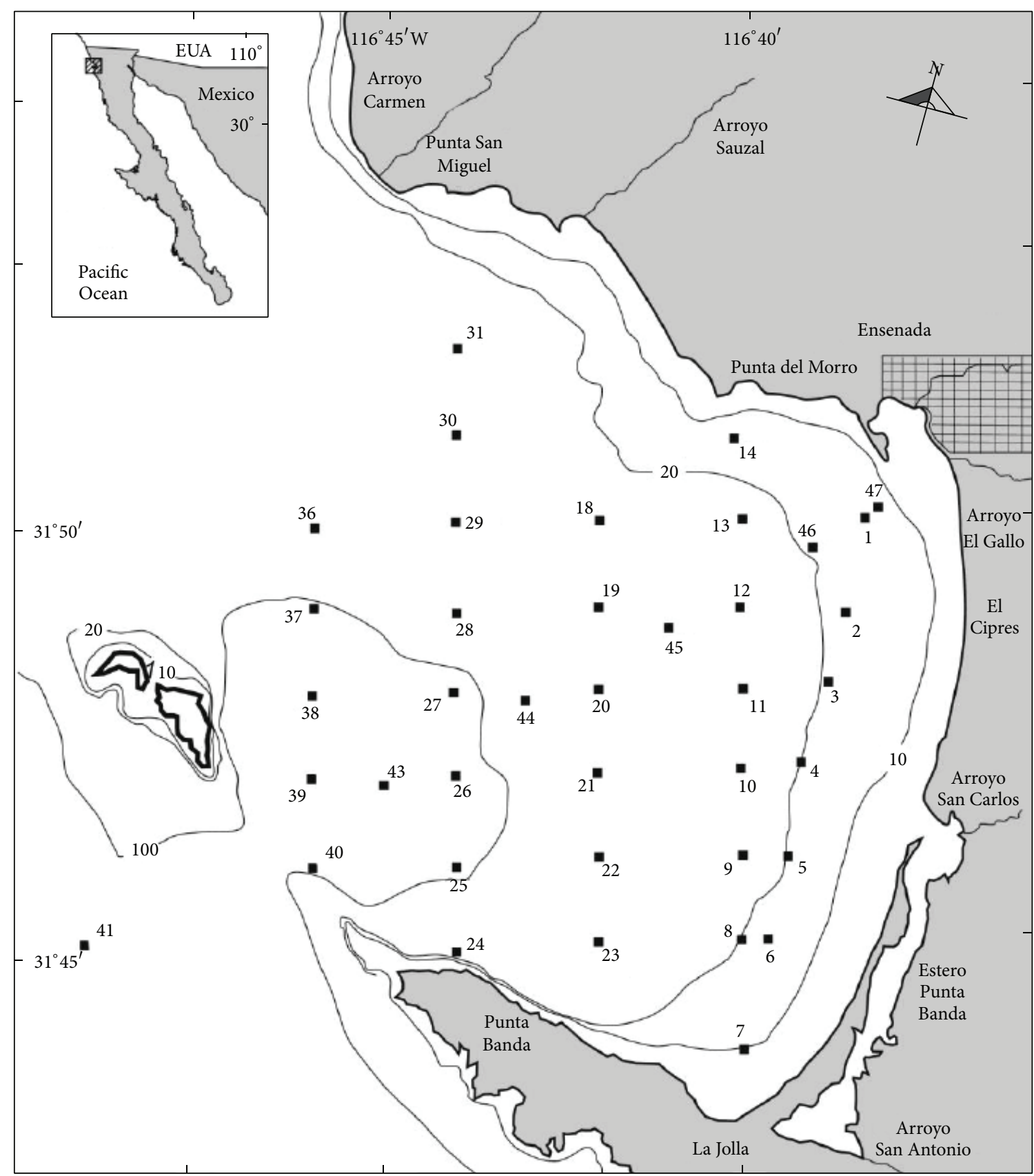

FIgure 1: Study area in Todos Santos Bay, Baja California: locations of sampling stations.

oyster culture increases the occurrence of anoxic conditions in the overlying water [17], but usually there are no differences of DO concentrations in oyster farming areas and control sites [18]. Hydrodynamic conditions at TSB can determine the local erosion and deposition of sediments as well as the oxygen supply at locations inside the bay.

Most mollusks studies in the Mexican Pacific Ocean are related to species of commercial importance and some pollution indicators [19-23], and few studies have dealt with noncommercial species, for example, in the coastal and continental shelf of Jalisco and Colima and the Gulf of Tehuantepec $[24,25]$. Recently, other studies of the malacological fauna in the region of Baja California were published [26-28]. One of these studies found 122 genera and 202 species; 11 endemic species of Gastropoda and Polyplacophora were collected [28]. However, in Todos Santos Bay, there are no malacological studies published although there are some publications of macroinvertebrate fauna, such as isopods and polychaetes $[11,29]$. Oxygen depletion in seawater impacts the abundance and distribution of benthic fauna. The response can vary in different species but a progressive stress has been observed as DO concentration decreases [30]. Although mollusks have been considered reliable indicators of human impacts [8, 31], there is little information on how these organisms are 
associated under natural conditions with oxygen concentrations. Crucial to our ecological understanding of coastal ecosystems are benthic communities; benthic fauna responds to anthropogenic disturbances and is therefore a useful tool for tracking environmental alterations [32,33]. The aim of this work is to determine the relationships between mollusk abundance and physicochemical properties of seawater and sediments under natural conditions of low impact.

\section{Material and Methods}

2.1. Sampling. A total of 39 stations (Figure 1) were sampled with a Van Veen grab $\left(0.1 \mathrm{~m}^{-2}\right)$ in October 1994 aboard the research vessel Francisco de Ulloa. Physicochemical data from the water column were obtained using a CTD at each station. Environmental data measured included temperature $\left({ }^{\circ} \mathrm{C}\right)$, salinity, and dissolved oxygen $\left(\mathrm{mL} \mathrm{L}^{-1}\right)$ at $1 \mathrm{~m}$ above the seafloor. Two sediment samples were taken per station, the first to analyze the macrofauna and the second to study sediment granulometry and organic matter content. Samples for macrofauna were sieved through nested 1.0 and $0.5 \mathrm{~mm}$ mesh screens, and organisms were previously relaxed with an $\mathrm{MgSO}_{4}$ solution during $10 \mathrm{~min}$ and fixed in $7 \%$ buffered formalin solution. In the laboratory, macrofauna was sorted to different zoological groups and stored in 70\% ethanol. Mollusca were identified to genus level using different taxonomic keys [34, 35]. Abundance (ind $0.1 \mathrm{~m}^{-2}$ ) per station and total abundance per genus (sum of all individuals) were calculated.

In sediments, organic matter content was determined by ignition loss [36]. To analyze sediment granulometry, $50 \mathrm{~g}$ samples were dry-sieved, through a series of mesh sizes (from 4.75 to $-4 \phi$ ), and mechanically shaken for $10 \mathrm{~min}$. Sediments retained on each sieve were weighted and the percentage of each granulometric category was calculated [37].

Environmental factors were associated with Pearson correlation $(\rho, P<0.05)$. Olmsted and Tukey test [38] was used to determine the frequent and abundant genera which were considered as dominant genera; total abundance data were transformed to $\log (X+1)$, and frequency was calculated dividing number of stations where the genera were present between total numbers of stations sampled and multiplied by 100. All genera that exceeded the mean of these values were considered dominant.

Factor analysis (FA) and principal component analysis (PCA) are indirect ordination methods for one matrix, and assume that variables have linear combinations. These analyses are similar to DCA but DCA uses a chi-square distance; besides, DCA give us the length of the gradient along the first axis; when the gradient length is $<3$, a redundancy analysis (RDA) is recommended, and when it is $>4$, a canonical correspondence analysis (CCA) is used according to ter Braak and Šmilauer [39]. Furthermore, DCA is a preliminary analysis previous to achieving a direct gradient analysis which relates two data matrices (biological and environmental factors).

In order to establish the relationship between mollusks and environmental factors, three detrended canonical analyses (DCA) were carried out with three abundance matrices: one without transformation, square root transformation, and $\log (X+1)$ transformation. Subsequently, a PCA or CCA analysis was performed depending on the gradient length. Direct gradient analysis relates abundance and composition of fauna to environmental factors, but this analysis does not explain which species are strongly related to the main gradient. However, this can be done with a generalized linear model (GLM) which does not assume a normal distribution. The relationship between abundance of each dominant mollusk genus and DO was analyzed using a negative binomial GLM using the R software package ver. 3.1.2 [40].

\section{Results}

Environmental factors are given in Table 1. The sampling depth at Todos Santos Bay varied between 7 and $400 \mathrm{~m}$, temperature between 8.1 and $17.8^{\circ} \mathrm{C}$, salinity from 33.4 to $34.2 \%$, dissolved oxygen from 1.0 to $5.6 \mathrm{~mL} \mathrm{~L}^{-1}$, organic matter content from 0.5 to $10.6 \%$, and silt-clay fraction from 1.2 to $99 \%$ [11]. Of these environmental factors, depth was positively correlated with salinity $(\rho=0.95, P<0.05)$ and OM $(\rho=0.92, P<0.05)$, and DO was positively correlated with temperature $(\rho=0.91, P<0.05)$ (Table 2$)$.

A total of 836 mollusks were collected: Gastropoda (52\%), Bivalvia (41\%), and Scaphopoda (7\%). Gastropoda was the most abundant and diverse class with 27 genera, followed by Bivalvia with eight genera and Scaphopoda with only one genus (Table 3). According to Olmstead and Tukey's method 13 genera were dominant which means they were extensively distributed and abundant, $\log (X+1)>1.27$ ind $=18$ ind, and frequent, $\mathrm{FO}>11.2 \%$ (Table 3 ).

Transformation of abundance data did not increase the percentage of variance explained by environmental factors; thus CCA was performed without data transformation. In order to diminish the factor of inflation of CCA analysis, environmental factor with high correlation $(>0.90)$ was not included in the analysis; thus temperature, salinity, and organic matter were not considered in this analysis. According to stepwise procedure dominant mollusks were related significantly with DO concentrations and explained $10 \%$ of the total variance of abundance and composition of Mollusca in Todos Santos Bay (Table 4). However, all axes of CCA analysis constructed with these environmental factors were significant which indicates that it is not a random pattern (Figure 2).

Thirteen genera were dominant: Donax, Natica, Acteocina, Bulla, Anachis, Odostomia, and Crucibulum, and they can be classified as sensitive genera because they were found mainly in high oxygen concentration $\left(3.1-5.6 \mathrm{~mL} \mathrm{~L}^{-1}\right)$; on the other hand, Cardiomya, Nuculana, Laevicardium, Chione, Truncatella, and Dentalium can be classified as tolerant genera (1.0-5.6 $\mathrm{mL} \mathrm{L}^{-1}$ ) (Figure 3). Of these genera, Truncatella, Bulla, Acteocina, and Donax were related to DO with a negative binomial GLM; the model explained $22-39 \%$ of the total variance (Figure 4).

\section{Discussion and Conclusion}

To our knowledge this is the first malacological study in Todos Santos Bay. In this work we compare our results with similar ecosystems near the study area and other regions. A 
TABLE 1: Environmental factors measured in Todos Santos Bay, Baja California.

\begin{tabular}{|c|c|c|c|c|c|c|}
\hline Station & Depth (m) & Temperature $\left({ }^{\circ} \mathrm{C}\right)$ & $\mathrm{DO}\left(\mathrm{mL} \mathrm{L}^{-1}\right)$ & Salinity & $\mathrm{OM}(\%)$ & Silt-clay (\%) \\
\hline 1 & 18 & 17.3 & 5.1 & 33.4 & 2.0 & 92.9 \\
\hline 2 & 19.6 & 15.6 & 5.4 & 33.4 & 1.5 & 96.9 \\
\hline 3 & 20 & 14.7 & 4.9 & 33.4 & 0.9 & 98.1 \\
\hline 4 & 20 & 13.9 & 4.6 & 33.4 & 0.5 & 1.2 \\
\hline 5 & 19.2 & 16.2 & 5.4 & 33.4 & 1.2 & 95.7 \\
\hline 6 & 15 & 15.0 & 5.0 & 33.4 & 0.9 & 95.4 \\
\hline 7 & 6.9 & 17.8 & 5.1 & 33.4 & 1.3 & 73.3 \\
\hline 8 & 19 & 14.6 & 5.1 & 33.4 & 1.8 & 94.5 \\
\hline 9 & 26.5 & 14.7 & 4.8 & 33.4 & 1.2 & 86.5 \\
\hline 10 & 25.8 & 14.2 & 5.2 & 33.4 & 1.6 & 96.8 \\
\hline 11 & 24.6 & 13.8 & 5.1 & 33.4 & 1.0 & 98.3 \\
\hline 12 & 24.8 & 14.1 & 5.5 & 33.4 & 1.3 & 98.1 \\
\hline 13 & 24 & 14.5 & 5.6 & 33.4 & 3.1 & 20.4 \\
\hline 14 & 19 & 14.7 & 5.1 & 33.4 & 1.9 & 78.2 \\
\hline 18 & 29 & 13.9 & 3.5 & 33.5 & 1.3 & 99.0 \\
\hline 19 & 30 & 13.8 & 4.2 & 33.5 & 0.9 & 98.9 \\
\hline 20 & 38 & - & - & - & 2.8 & 83.0 \\
\hline 21 & 47.7 & 13.0 & 3.2 & 33.5 & 3.2 & 96.0 \\
\hline 22 & 51 & 13.3 & 3.8 & 33.5 & 2.3 & 95.1 \\
\hline 23 & 46 & 13.9 & 4.7 & 33.4 & 2.2 & 87.3 \\
\hline 24 & 62.5 & 12.5 & 3.5 & 33.6 & 4.4 & 78.8 \\
\hline 25 & 102.2 & 11.7 & 2.1 & 33.8 & 2.3 & 40.3 \\
\hline 26 & 210 & 9.7 & 1.4 & 34.2 & 9.1 & 60.6 \\
\hline 27 & 188 & 10.6 & 1.3 & 34.0 & 6.1 & 84.6 \\
\hline 28 & 47.7 & 13.3 & 3.4 & 33.5 & 2.0 & 97.4 \\
\hline 29 & 37.5 & 13.7 & 4.0 & 33.5 & 1.8 & 97.9 \\
\hline 30 & 34 & 13.7 & 4.6 & 33.4 & - & - \\
\hline 31 & 34.5 & 13.7 & 3.2 & 33.5 & - & - \\
\hline 36 & 43.6 & 13.0 & 3.5 & 33.5 & 1.5 & 32.9 \\
\hline 37 & 165 & 10.2 & 1.4 & 34.1 & 7.4 & 88.0 \\
\hline 38 & 238 & 9.1 & 1.4 & 34.2 & 5.6 & 95.5 \\
\hline 39 & 342 & 8.2 & 1.1 & 34.2 & 10.6 & 84.4 \\
\hline 40 & 75 & 12.5 & 3.1 & 33.6 & 4.8 & 14.8 \\
\hline 41 & 400 & - & - & - & - & 95.8 \\
\hline 43 & 295 & 8.1 & 1.0 & 34.2 & - & 98.4 \\
\hline 44 & 63.6 & 12.0 & 2.9 & 33.7 & 3.6 & 98.4 \\
\hline 45 & 27.5 & 14.9 & 5.2 & 33.4 & 1.1 & 98.4 \\
\hline 46 & 22.7 & 14.4 & 4.5 & 33.4 & 2.1 & 91.1 \\
\hline 47 & 18.2 & 15.6 & 4.9 & 33.4 & 2.3 & 91.1 \\
\hline
\end{tabular}

TABLE 2: Correlation coefficient of environmental factors, dissolved oxygen (DO), and organic matter (OM); $N=34,{ }^{*} P>0.05$.

\begin{tabular}{|c|c|c|c|c|c|c|}
\hline Environmental factors & Depth & Temperature & $\mathrm{DO}$ & Salinity & $\mathrm{OM}$ & Silt-clay \\
\hline Depth (m) & 1.00 & & & & & \\
\hline Temperature $\left({ }^{\circ} \mathrm{C}\right)$ & $-0.88^{*}$ & 1.00 & & & & \\
\hline $\mathrm{DO}\left(\mathrm{mL} \mathrm{L}^{-1}\right)$ & $-0.87^{*}$ & $0.91^{*}$ & 1.00 & & & \\
\hline Salinity & $0.95^{*}$ & $-0.90^{*}$ & $-0.93^{*}$ & 1.00 & & \\
\hline $\mathrm{OM}(\%)$ & $0.92^{*}$ & $-0.82^{*}$ & $-0.82^{*}$ & $0.90^{*}$ & 1.00 & \\
\hline Silt-clay (\%) & -0.05 & 0.13 & 0.11 & -0.06 & -0.11 & 1.00 \\
\hline
\end{tabular}


TABle 3: Abundance and frequency of mollusks in Todos Santos Bay. Dominant genera* .

\begin{tabular}{|c|c|c|c|}
\hline Class & Genera & Total abundance (ind) & Frequency (\%) \\
\hline \multirow{8}{*}{ Bivalvia } & Donax* & 120 & 48.8 \\
\hline & Nuculana* & 67 & 41.5 \\
\hline & Laevicardium ${ }^{*}$ & 41 & 17.1 \\
\hline & Cardiomya* & 41 & 24.4 \\
\hline & Chione $^{*}$ & 25 & 14.6 \\
\hline & Modiolus & 17 & 14.6 \\
\hline & Pecten & 16 & 12.2 \\
\hline & Solen & 13 & 9.8 \\
\hline \multirow{27}{*}{ Gastropoda } & Anachis* & 40 & 24.4 \\
\hline & Odostomia* & 35 & 12.2 \\
\hline & Truncatella* & 30 & 12.2 \\
\hline & Acteocina* $^{*}$ & 26 & 12.2 \\
\hline & Crucibulum* & 23 & 12.2 \\
\hline & Epitonium & 22 & 9.8 \\
\hline & Natica $^{*}$ & 19 & 12.2 \\
\hline & Nassarius & 18 & 7.3 \\
\hline & Bulla* & 18 & 17.1 \\
\hline & Caecum & 18 & 9.8 \\
\hline & Bittium & 18 & 4.9 \\
\hline & Olivella & 16 & 9.8 \\
\hline & Turbonilla & 16 & 7.3 \\
\hline & Jenneria & 15 & 7.3 \\
\hline & Lacuna & 15 & 7.3 \\
\hline & Calyptraea & 14 & 4.9 \\
\hline & Polimices & 13 & 14.6 \\
\hline & Barleeia & 12 & 7.3 \\
\hline & Pyramidella & 11 & 4.9 \\
\hline & Cyclostremiscus & 11 & 4.9 \\
\hline & Assiminea & 10 & 7.3 \\
\hline & Littorina & 9 & 4.9 \\
\hline & Teinostoma & 8 & 7.3 \\
\hline & Alvinia & 7 & 7.3 \\
\hline & Eulima & 4 & 4.9 \\
\hline & Balcis & 4 & 4.9 \\
\hline & Cerithidea & 4 & 4.9 \\
\hline Scaphopoda & Dentalium $^{*}$ & 60 & 36.6 \\
\hline
\end{tabular}

TABLE 4: Results of stepwise selection which relates significant environmental factors with mollusk genera. ${ }^{*} P>0.05$. Eigenvalues $=3.197$.

\begin{tabular}{lcccc}
\hline Explanatory environmental factors & Eigenvalue & $F$ & $P$ & Explained variance (\%) \\
\hline Dissolved oxygen $\left(\mathrm{mL} \mathrm{L}^{-1}\right)$ & 0.333 & 3.372 & $0.002^{*}$ & 10.4 \\
Silt-clay (\%) & 0.124 & 1.325 & 0.236 & 3.9 \\
Depth $(\mathrm{m})$ & 0.118 & 1.216 & 0.258 & 3.7 \\
\hline
\end{tabular}

study performed in 2011 recorded 18 genera at $31^{\circ} \mathrm{N}$ which is the same latitude as TSB; in that study most stations were located at more than $200 \mathrm{~m}$ depth [27]. This genera abundance is low compared with the 36 genera collected in this study; however, it is low compared to tropical Guanabara Bay located in Brazil with 46 genera [41], but it is close to the subtropical Mersin Bay in Turkey with 35 genera [42].
A relevant difference is observed with only eight genera of bivalves found in this study with respect to 55 genera recorded in the subtropical Mazatlán Bay in Mexico [43]. 75\% of the genera collected in TSB were gastropods; this high percentage has also been observed in Sinaloa coastal region where $70 \%$ of the species belong to this class [28], and according to Castillo-Rodríguez [44] the class Gastropoda is usually more 


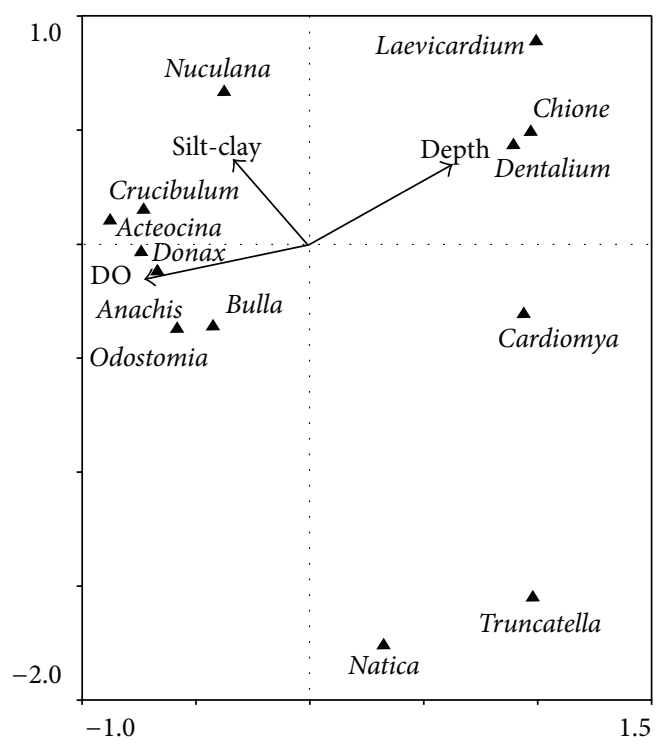

FIGURE 2: CCA analysis relations between dominant mollusks, dissolved oxygen (DO), silt-clay, and depth in Todos Santos Bay. First canonical axis $(F=3.454, P=0.002)$; all canonical axes $(F=1.995, P=0.004)$.

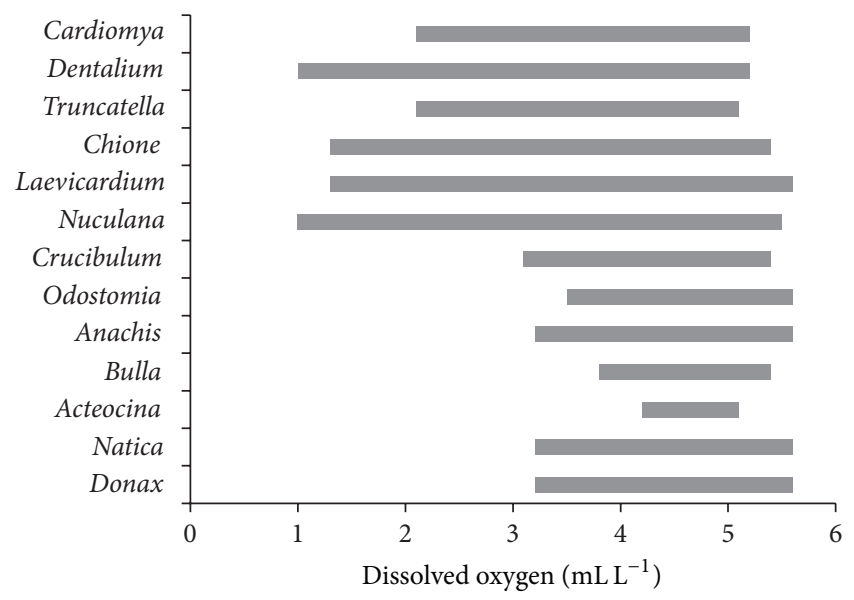

FIGURE 3: Range of dissolved oxygen concentrations for the thirteen dominant genera of mollusks.

diverse than Bivalvia. Differences in genera composition and abundances can be related to the method used to collect the mollusks (grab, trawl) and also depend on the sampling effort.

We did not observe a clear relationship between sediment type and the genera composition of mollusks, which has been described in other malacological studies [41, 42]; but we found that mollusks were related with dissolved oxygen (DO) concentrations near the seafloor ( $10 \%$ of total variance). The differences found could be due to the identification level (genus) while other studies have been done to species level. Some research has described malacological fauna and DO; for example, Zamorano et al. [26] described a segregation of mollusk species from the range of 0.04 to $2.20 \mathrm{~mL} \mathrm{~L}^{-1}$ DO concentrations in the Gulf of California, Mexico, where bivalves dominated in low DO concentrations and the

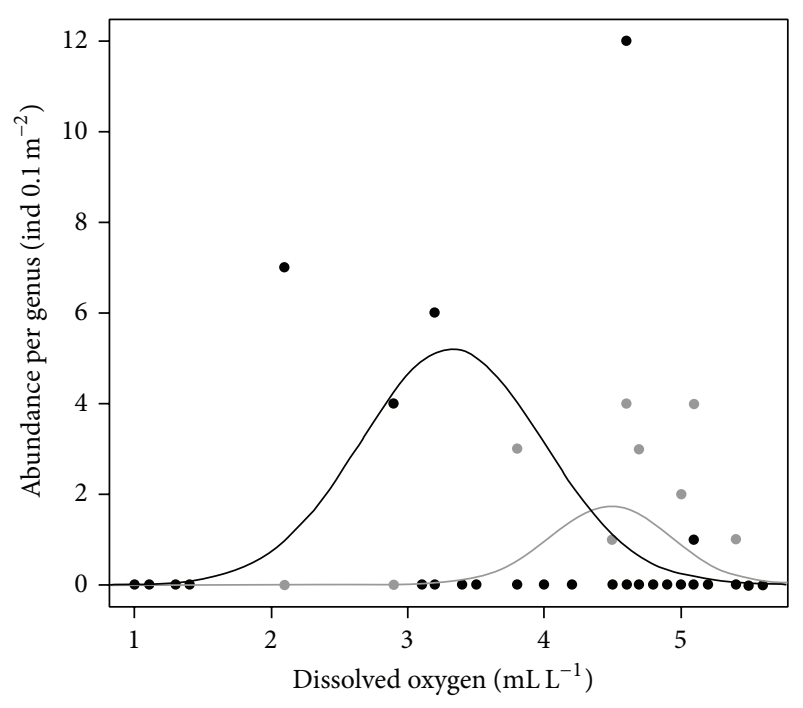

- Truncatella

- Bulla

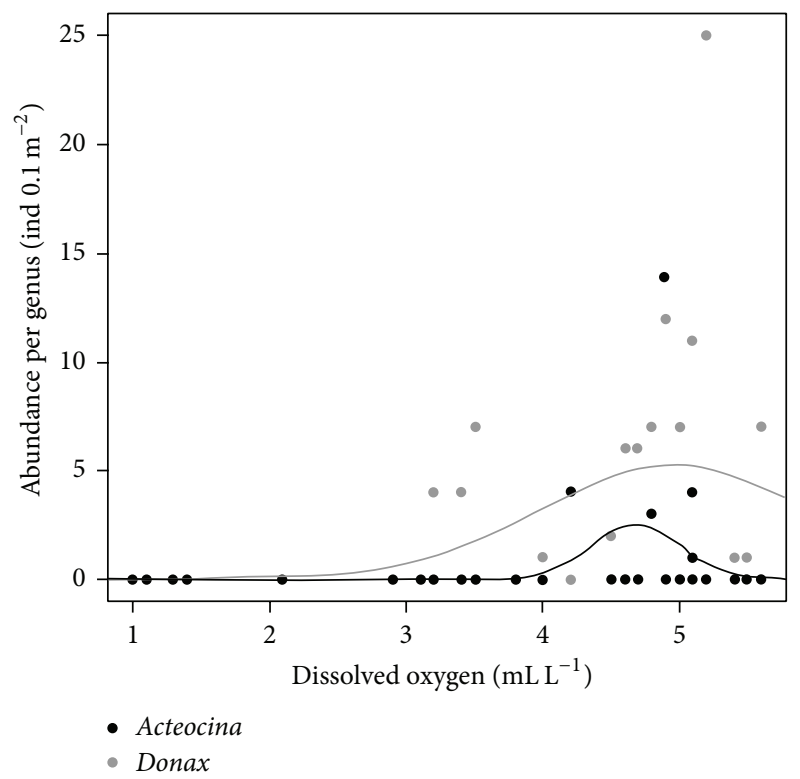

FIGURE 4: Negative binomial generalized linear models (lines) fitted for mollusk abundance per genus (dots) in relation to oxygen concentrations.

scaphopod Dentalium agassizi was present in almost all the ranges of DO measured. Another work found two groups of species but only gastropods were related to a DO gradient in Guanabara Bay, Rio de Janeiro, Brazil; in this case, the first group was conformed by Natica pusilla, Acteocina bidentate, Olivella minuta, and Turbonilla sp., while the second group was conformed by Anachis isabellei, Heleobia australis, and Nassarius vibex [41].

Species inhabiting oxygen minimum zones (OMZ) require specific behavioral adaptations; for example, zooplankton migrates to well oxygenated waters and the pteropod Diacria quadridentata reduces oxygen consumption and ammonia excretion in $\operatorname{OMZ}[45,46]$. Taxa most tolerant to severe oxygen depletion $\left(0.2 \mathrm{~mL} \mathrm{~L}^{-1}\right)$ in seafloor include 
calcareous foraminiferans, nematodes, and annelids; calcified invertebrates are usually less tolerant [47]. Under hypoxic conditions, benthic bivalves reduce their burial depth and siphon extension increases during severe hypoxia, provoking anaerobic energy production in the bivalves [48-50].

Many benthic organisms (polychaetes, annelids, crustaceans, bivalves, priapulids, and anemones) leave their burrows or tubes to move to the sediment surface or reduce their burial depth in the presence of hypoxia. Other bivalves species stretch their siphons upward into the water column to reach waters with higher oxygen concentrations. They also acknowledge that some gastropods climb structures to reach waters with higher oxygen concentration. Metabolic adaptations to cope with hypoxia include depression of activity in the presence of hypoxia and reduced feeding activity in some crustaceans, mollusks, and polychaetes [51].

Mollusks are the macrofauna phylum least sensitive to organic matter enrichment and $\mathrm{H}_{2} \mathrm{~S}$ accumulation, while crustaceans, echinoderms, and annelids such as polychaetes show an intermediate response [52]. In the Adriatic Sea, Corbula gibba is a clear example of an opportunistic species [53] because it is frequently found in hypoxic conditions $\left(<2 \mathrm{~mL} \mathrm{~L}^{-1}\right)$ and after postanoxic periods $[54,55]$. It has been demonstrated that C. gibba can survive for $78 \mathrm{~h}$ in anoxic conditions [56]. In the present study, Dentalium, Chione, Laevicardium, and Nuculana were found in low DO concentrations $\left(<2 \mathrm{~mL} \mathrm{~L}^{-1}\right)$; furthermore, these genera of bivalves are relatively tolerant to low oxygen levels in Todos Santos Bay. The high dominance of tolerant genera and species previously mentioned could be indicators of hypoxic conditions $\left(<2 \mathrm{~mL} \mathrm{~L}^{-1}\right)$. The increase of human populations in coastal zones contributes to promoting sites with low levels of DO [9]. Other species belonging to families Naticidae and Acteocinidae, such as Natica pusilla and Acteocina bidentata, have been found in well oxygenated waters in Guanabara Bay, Rio de Janeiro, Brazil [41]. In our study, genera Natica and Acteocina were collected in high oxygen concentrations in the north and central sections of the bay (stations 1, 3, 9, 4, $13,14,19$, and 21). Although mollusks have been extensively employed in bioaccumulation studies for metal pollution $[7,8,31]$, other studies have evaluated their utility as indicator of oxygen depletion in coastal environments [53,55-57]. We acknowledge that only four genera of the thirteen dominant mollusks collected at TSB were related significantly to DO concentrations by a negative binomial GLM, which means that Truncatella, Donax, Bulla, and Acteocina follow a natural gradient of DO in Todos Santos Bay, Baja California.

It has been demonstrated that $50 \%$ of coastal marine animal species die after exposure to oxygen levels lower than $\sim 70 \mu \mathrm{mol} \mathrm{kg}^{-1}\left(1.6 \mathrm{~mL} \mathrm{~L}^{-1}\right)$ [51]. Dissolved oxygen is essential to life [58] because it supports the biological elements (phytoplankton, nekton, and benthos) according to the Water Framework Directive (WFD, 2000/60/EC). The dependence of marine organisms on dissolved oxygen concentrations, such as benthic invertebrates and fish, is necessary in the assessment of ecosystem health of marine environments [58]. This is relevant because in the last two decades there has been an increased concern of anthropogenic impacts in coastal areas and severe oxygen deficiencies have been reported in different regions of the world [59].

Benthic indices have been developed to determine the ecological status of marine ecosystems in coastal environments [60,61]; nevertheless, their use has been limited because we lack information on how organisms are related to environmental factors under natural conditions in other aquatic systems. Some mollusks classified as sensitive genera in this study are included in the lists of BENTIX and AMBI indices in the same ecological group of sensitive organisms $[60,61]$. In accordance with the results of this study, Acteocina, Bulla, Anachis, and Crucibulum could be included as tolerant genera in the BENTIX list. It is worth mentioning that the mollusks even at genera level, classified as tolerant in the present study, have been classified as sensitive by both indices lists (BENTIX and AMBI). We demonstrated that these genera embrace a wide range of dissolved oxygen concentrations in TSB. These results must be used with caution because species of the same genera show different mortality rates and behavior under hypoxic conditions in other regions [62]. This approach can be used with other benthic organisms, such as polychaetes and crustaceans to determine the possible classification of the ecological groups according to DO concentrations.

The mussel aquaculture in the south part of TSB was not playing an important role in the environmental condition when these samples were collected (1994), as most of the stations $(6,7,8$, and 23$)$ near the aquaculture area presented high dissolved oxygen concentrations $\geq 4.7 \mathrm{~mL} \mathrm{~L}^{-1}$. This could be explained because sampling took place during the initial stages of mussel aquaculture activities, and sometimes it has been difficult to find differences of DO concentrations in oyster farming areas and control sites [18]. Another factor could be that currents are stronger in the southern area and near the mouth [15], which could favor that the excess of produced organic matter is transported to other areas. It would be interesting to sample again the stations near the aquaculture area and confirm if this activity has had an effect on dissolved oxygen concentrations during the last 22 years and check if the tolerant mollusk genera determined in this study are still present in this impacted area.

In conclusion, Todos Santos Bay hosts a diverse malacological fauna (36 genera) compared to sites at $31^{\circ} \mathrm{N}$. Our results show that Donax, Natica, Acteocina, Bulla, Anachis, Odostomia, and Crucibulum can be classified as sensitive genera, which were strongly related to a narrow range of high dissolved oxygen concentrations, whereas Cardiomya, Nuculana, Laevicardium, Chione, Truncatella, and Dentalium can be classified as tolerant genera because they live in a wide interval of DO concentrations. Mollusca can be a useful tool in environmental monitoring programs related with oxygen depletion as mariculture and other human activities can favor eutrophication in coastal environments.

\section{Competing Interests}

The authors declare that there is no conflict of interests regarding the publication of this paper. 


\section{Acknowledgments}

The authors thank R. Jiménez and M. Mondragón for their technical assistance in sorting samples and the crew who took part in BAHIA-I-10-94 cruise. Support for this project was provided by CONACYT for the research project to V. DíazCastañeda and the postdoctoral scholarship granted to J. G. Kuk-Dzul.

\section{References}

[1] Z.-Q. Zhang, "Animal biodiversity: an introduction to higherlevel classification and taxonomic richness," Zootaxa, vol. 3148, pp. 7-12, 2011.

[2] R. I. E. Newell, "Ecosystem influences of natural and cultivated populations of suspension-feeding bivalve molluscs: a review," Journal of Shellfish Research, vol. 23, no. 1, pp. 51-61, 2004.

[3] E. Baqueiro Cardenas, "Status of molluscan aquaculture on the Pacific coast of Mexico," Aquaculture, vol. 39, no. 1-4, pp. 83-93, 1984.

[4] L. R. Martínez-Córdova, "Contribution to the knowledge of the malacological fauna of four costal lagoons in the state of Sonora, Mexico," Ciencias Marinas, vol. 22, no. 2, pp. 191-203, 1996.

[5] L. M. Flores-Campaña, M. A. González-Montoya, M. A. OrtizArellano, and J. F. Arzola-González, "Estructura poblacional de Chiton articulatus en las islas Pájaros y Venados de la bahía de Mazatlán, Sinaloa, México," Revista Mexicana de Biodiversidad, vol. 78, pp. 23-31, 2007.

[6] A. Aneiros and A. Garateix, "Bioactive peptides from marine sources: pharmacological properties and isolation procedures," Journal of Chromatography B: Analytical Technologies in the Biomedical and Life Sciences, vol. 803, no. 1, pp. 41-53, 2004.

[7] I. Rosas, A. Báez, and R. Belmont, "Oyster (Crassostrea virginica) as indicator of heavy metal pollution in some lagoons of the Gulf of Mexico," Water, Air, and Soil Pollution, vol. 20, no. 2, pp. 127-135, 1983.

[8] F. Páez-Osuna and C. Osuna-Martínez, "Biomonitores de la contaminación costera con referencia a las costas mexicanas: una revisión sobre los organismos utilizados," Hidrobiológica, vol. 21, no. 3, pp. 229-238, 2011.

[9] R. J. Diaz, "Overview of hypoxia around the world," Journal of Environmental Quality, vol. 30, no. 2, pp. 275-281, 2001.

[10] R. Aguilar-Rosas, L. E. Aguilar-Rosas, G. E. Á. Serrano, Ó. G. Yajimovich, and F. B. Bobadilla, "Submareal macroalgae of the Todos Santos Bay, Baja California, Mexico," Revista Mexicana de Biodiversidad, vol. 81, no. 3, pp. 601-618, 2010.

[11] V. Díaz-Castañeda and L. H. Harris, "Biodiversity and structure of the polychaete fauna from soft bottoms of Bahia Todos Santos, Baja California, Mexico," Deep-Sea Research Part II: Topical Studies in Oceanography, vol. 51, no. 6-9, pp. 827-847, 2004.

[12] L. G. Álvarez-Sánchez, R. Hernández-Walls, and R. DurazoArvizu, "Drift patterns of lagrangian tracers in Todos Santos Bay," Ciencias Marinas, vol. 14, no. 4, pp. 135-162, 1988.

[13] A. Sánchez and J. D. Carriquiry, "Sediment transport patterns in Todos Santos Bay, Baja California, Mexico, inferred from grainsize trends," in Sediment Transport in Aquatic Environments, A. J. Manning, Ed., pp. 3-18, InTech, Rijeka, Croatia, 2011.

[14] E. Mateos, S. G. Marinone, and A. Parés-Sierra, "Towards the numerical simulation of the summer circulation in Todos
Santos Bay, Ensenada, B.C. Mexico," Ocean Modelling, vol. 27, no. 1-2, pp. 107-112, 2009.

[15] I. G. Cervantes Audelo, Análisis de circulación y dispersión en la Bahía de Todos Santos, Baja California [M.S. thesis], Universidad del Mar, Oaxaca, Mexico, 2013.

[16] A. C. Ostricultores de Baja California, Programa Maestro Sistema Producto Ostión, CONAPESCA, 2008.

[17] N. Mazouni, J.-C. Gaertner, and J.-M. Deslous-Paoli, "Influence of oyster culture on water column characteristics in a coastal lagoon (Thau, France)," Hydrobiologia, vol. 373-374, pp. 149-156, 1998.

[18] M. C. S. da Cruz, S. F. Fróes Costa, R. C. Ferreira, R. L. Nascimento, and T. K. de Oliveira Pinto, "Impact assessment related to an oyster farming on the benthic environment," Boletim do Instituto de Pesca, vol. 41, no. 2, pp. 207-218, 2015.

[19] E. Ríos-Jara, M. Pérez-Peña, R. Beas-Luna, E. López-Uriarte, and E. Juárez-Carrillo, "Gastropods and bivalves of commercial interest from the continental shelf of Jalisco and Colima, México," Revista de Biologia Tropical, vol. 49, no. 3, pp. 859-863, 2001.

[20] H. Wright-López, O. Holguín-Quiñones, F. Arreguín-Sánchez, and I. Roque-Villada, "Crecimiento y mortalidad de la concha nácar Pteria sterna en bancos silvestres de Baja California Sur, México," Revista de Biología Tropical, vol. 57, no. 3, pp. 659-670, 2009.

[21] L. Cadena-Cárdenas, L. Méndez-Rodríguez, T. Zenteno-Savín, J. García-Hernández, and B. Acosta-Vargas, "Heavy metal levels in marine mollusks from areas with, or without, mining activities along the Gulf of California, Mexico," Archives of Environmental Contamination and Toxicology, vol. 57, no. 1, pp. 96-102, 2009.

[22] J. Cáceres-Martínez, R. Vásquez-Yeomans, G. PadillaLardizábal, and M. A. del Río Portilla, "Perkinsus marinus in pleasure oyster Crassostrea corteziensis from Nayarit, Pacific coast of México," Journal of Invertebrate Pathology, vol. 99, no. 1, pp. 66-73, 2008.

[23] C. Escobedo-Fregoso, L. C. Mendez-Rodriguez, P. MonsalvoSpencer, R. A. Llera-Herrera, T. Zenteno-Savin, and B. AcostaVargas, "Assessment of metallothioneins in tissues of the clam Megapitaria squalida as biomarkers for environmental cadmium pollution from areas enriched in phosphorite," Archives of Environmental Contamination and Toxicology, vol. 59, no. 2, pp. 255-263, 2010.

[24] E. Ríos-Jara, E. López-Uriarte, and C. M. Galván-Villa, "Bivalve molluscs from the continental shelf of Jalisco and Colima, Mexican Central Pacific," American Malacological Bulletin, vol. 26, no. 1-2, pp. 119-131, 2008.

[25] E. Ríos-Jara, C. Navarro-Caravantes, C. Galván-Villa, and E. Lopez-Uriarte, "Bivalves and gastropods of the Gulf of Tehuantepec, Mexico: a checklist of species with notes on their habitat and local distribution," Journal of Marine Biology, vol. 2009, Article ID 176801, 12 pages, 2009.

[26] P. Zamorano, M. E. Hendrickx, and A. Toledano-Granados, "Distribution and ecology of deep-water mollusks from the continental slope, southeastern Gulf of California, Mexico," Marine Biology, vol. 150, no. 5, pp. 883-892, 2007.

[27] P. Zamorano and M. E. Hendrickx, "State of knowledge about the community of mollusks on both sides of the Baja California Peninsula, Mexico: a comparative analysis," Cahiers de Biologie Marine, vol. 52, no. 1, pp. 13-22, 2011.

[28] M. E. Hendrickx, J. Salgado-Barragán, A. Toledano-Granados, and M. Cordero-Ruiz, "Los moluscos (Pelecypoda, Gastropoda, 
Cephalopoda, Polyplacophora y Scaphopoda) recolectados en el SE del golfo de California durante las campañas SIPCO a bordo del B/O 'El Puma'. Elenco faunístico," Revista Mexicana de Biodiversidad, vol. 85, no. 3, pp. 682-722, 2014.

[29] E. Campos and G. Villarreal, "Littoral and shallow water isopods from Todos los Santos Bay, Baja California, Mexico," Revista Mexicana de Biodiversidad, vol. 79, no. 2, pp. 347-354, 2008.

[30] N. N. Rabalais and R. E. Turner, "Responses of nekton and demersal and benthic fauna to decreasing oxygen concentrations," in Coastal Hypoxia: Consequences for Living Resources and Ecosystems, N. N. Rabalais, D. E. Jr. Harper, and R. E. Turner, Eds., vol. 58 of Coastal and Estuarine Studies, pp. 115128, American Geophysical Union, Washington, DC, USA, 2001.

[31] E. R. Baqueiro-Cárdenas, L. Borabe, C. G. Goldaracena-Islas, and J. Rodríguez-Navarro, "Los moluscos y la contaminación: una revisión," Revista Mexicana de Biodiversidad, vol. 78, pp. 17, 2007.

[32] C. J. Calabretta and C. A. Oviatt, "The response of benthic macrofauna to anthropogenic stress in Narragansett Bay, Rhode Island: a review of human stressors and assessment of community conditions," Marine Pollution Bulletin, vol. 56, no. 10, pp. 1680-1695, 2008.

[33] V. M. Diaz-Castañeda and D. Reish, "Polychaetes in environmental studies," in Annelids in Modern Biology, D. H. Shain, Ed., pp. 205-227, John Wiley \& Sons, New York, NY, USA, 2009.

[34] E. V. Coan, D. J. Eernisse, F. G. Hochberg, A. H. Scheltema, P. H. Scott, and R. L. Shimek, "The mollusca, volume 8, part 1: aplacophora, polyplacophora, scaphopoda, bivalvia, and cephalopoda," in Taxonomic Atlas of the Benthic Fauna of the Santa Maria Basin and Western Santa Barbara Channel, P. V. Scott and J. A. Blake, Eds., Museum of Natural History, Santa Barbara, Calif, USA, 1996.

[35] J. H. McLean and T. M. Gosliner, "The mollusca, part 2: the gastropoda," in Taxonomic Atlas of the Benthic Fauna of the Santa Maria Basin and Western Santa Barbara Channel, P. V. Scott and J. A. Blake, Eds., vol. 9, Museum of Natural History, Santa Barbara, Calif, USA, 1996.

[36] W. Dean, "Determination of carbonate and organic matter in calcareous sediments and sedimentary rocks by loss on ignition: comparison with other methods," Journal of Sediment Petrology, vol. 44, pp. 242-248, 1974.

[37] H. Rump and H. Krist, Laboratory Manual for the Examination of Water, Waste Water and Soil, John Wiley \& Sons, Weinheim, Germany, 1992.

[38] R. Sokal and F. J. Rohlf, Biometry, Freeman, New York, NY, USA, 1995.

[39] C. J. F. ter Braak and P. Šmilauer, CANOCO Reference Manual and CanoDraw for Windows User's Guide: Software for Canonical Community Ordination (Version 4.5), Microcomputer Power, Ithaca, NY, USA, 2002.

[40] R Development Core Team, $R$ : A Language and Environment for Statistical Computing, R Foundation for Statistical Computing, Vienna, Austria, 2008.

[41] R. A. F. Neves, C. A. Echeverria, L. A. Pessoa, P. C. Paiva, R. Paranhos, and J. L. Valentin, "Factors influencing spatial patterns of molluscs in a eutrophic tropical bay," Journal of the Marine Biological Association of the United Kingdom, vol. 93, no. 3, pp. 577-589, 2013.
[42] E. Mutlu and M. B. Ergev, "Distribution of soft-bottom mollusks (Mollusca) in Mersin Bay (eastern Mediterranean Sea)," Turkish Journal of Zoology, vol. 36, no. 4, pp. 430-446, 2012.

[43] M. D. C. Esqueda-González, E. Ríos-Jara, C. M. GalvánVilla, and F. A. Rodríguez-Zaragoza, "Species composition, richness, and distribution of marine bivalve molluscs in Bahía de Mazatlán, México," ZooKeys, vol. 399, pp. 43-69, 2014.

[44] Z. G. Castillo-Rodríguez, "Biodiversidad de moluscos marinos en México," Revista Mexicana de Biodiversidad, vol. 85, supplement 1, pp. 419-430, 2014.

[45] B. A. Seibel, "Critical oxygen levels and metabolic suppression in oceanic oxygen minimum zones," The Journal of Experimental Biology, vol. 214, no. 2, pp. 326-336, 2011.

[46] A. E. Maas, K. F. Wishner, and B. A. Seibel, "The metabolic response of pteropods to acidification reflects natural $\mathrm{CO}_{2}$ exposure in oxygen minimum zones," Biogeosciences, vol. 9, no. 2, pp. 747-757, 2012.

[47] L. A. Levin, "Oxygen minimum zone benthos: adaptation and community response to hypoxia," Oceanography and Marine Biology, vol. 41, pp. 1-45, 2003.

[48] D. L. Taylor and D. B. Eggleston, "Effects of hypoxia on an estuarine predator-prey interaction: foraging behavior and mutual interference in the blue crab Callinectes sapidus and the infaunal clam prey Mya arenaria," Marine Ecology Progress Series, vol. 196, pp. 221-237, 2000.

[49] W. C. Long, B. J. Brylawski, and R. D. Seitz, "Behavioral effects of low dissolved oxygen on the bivalve Macoma balthica," Journal of Experimental Marine Biology and Ecology, vol. 359, no. 1, pp. 34-39, 2008.

[50] A.-C. Lee, Y.-C. Lee, and T.-S. Chin, "Effects of low dissolved oxygen on the digging behaviour and metabolism of the hard clam (Meretrix lusoria)," Aquaculture Research, vol. 43, no. 1, pp. 1-13, 2012.

[51] R. Vaquer-Sunyer and C. M. Duarte, "Thresholds of hypoxia for marine biodiversity," Proceedings of the National Academy of Sciences of the United States of America, vol. 105, no. 40, pp. 15452-15457, 2008.

[52] J. S. Gray, R. S.-S. Wu, and Y. O. Ying, "Effects of hypoxia and organic enrichment on the coastal marine environment," Marine Ecology Progress Series, vol. 238, pp. 249-279, 2002.

[53] V. Nerlović, A. Doğan, and M. Hrs-Brenko, "Response to oxygen deficiency (depletion): bivalve assemblages as an indicator of ecosystem instability in the northern Adriatic Sea," Biologia, vol. 66, no. 6, pp. 1114-1126, 2011.

[54] S. P. Baden, L.-O. Loo, L. Pihl, and R. Rosenberg, "Effects of eutrophication on benthic communities including fish: Swedish West Coast," AMBIO, vol. 19, no. 3, pp. 113-122, 1990.

[55] B. Riedel, M. Zuschin, and M. Stachowitsch, "Tolerance of benthic macrofauna to hypoxia and anoxia in shallow coastal seas: a realistic scenario," Marine Ecology Progress Series, vol. 458, pp. 39-52, 2012.

[56] B. Riedel, T. Pados, K. Pretterebner et al., "Effect of hypoxia and anoxia on invertebrate behaviour: ecological perspectives from species to community level," Biogeosciences, vol. 11, no. 6, pp. 1491-1518, 2014.

[57] S. P. Holmes and N. Miller, "Aspects of the ecology and population genetics of the bivalve Corbula gibba," Marine Ecology Progress Series, vol. 315, pp. 129-140, 2006.

[58] M. A. Best, A. W. Wither, and S. Coates, "Dissolved oxygen as a physico-chemical supporting element in the Water Framework Directive," Marine Pollution Bulletin, vol. 55, no. 1-6, pp. 53-64, 2007. 
[59] B. Riedel, M. Zuschin, A. Haselmair, and M. Stachowitsch, "Oxygen depletion under glass: behavioural responses of benthic macrofauna to induced anoxia in the Northern Adriatic," Journal of Experimental Marine Biology and Ecology, vol. 367, no. 1, pp. 17-27, 2008.

[60] A. Borja, J. Franco, and V. Pérez, "A marine biotic index to establish the ecological quality of soft-bottom benthos within European estuarine and coastal environments," Marine Pollution Bulletin, vol. 40, no. 12, pp. 1100-1114, 2000.

[61] N. Simboura and A. Zenetos, "Benthic indicators to use in ecological quality classification of Mediterranean soft bottom marine ecosystems, including a new Biotic Index," Mediterranean Marine Science, vol. 3, no. 2, pp. 77-111, 2002.

[62] R. Diaz and R. Rosenberg, "Marine benthic hypoxia: a review of its ecological effects and the behavioral responses of benthic macrofauna," Oceanography and Marine Biology: and Annual Review, vol. 33, pp. 245-303, 1995. 

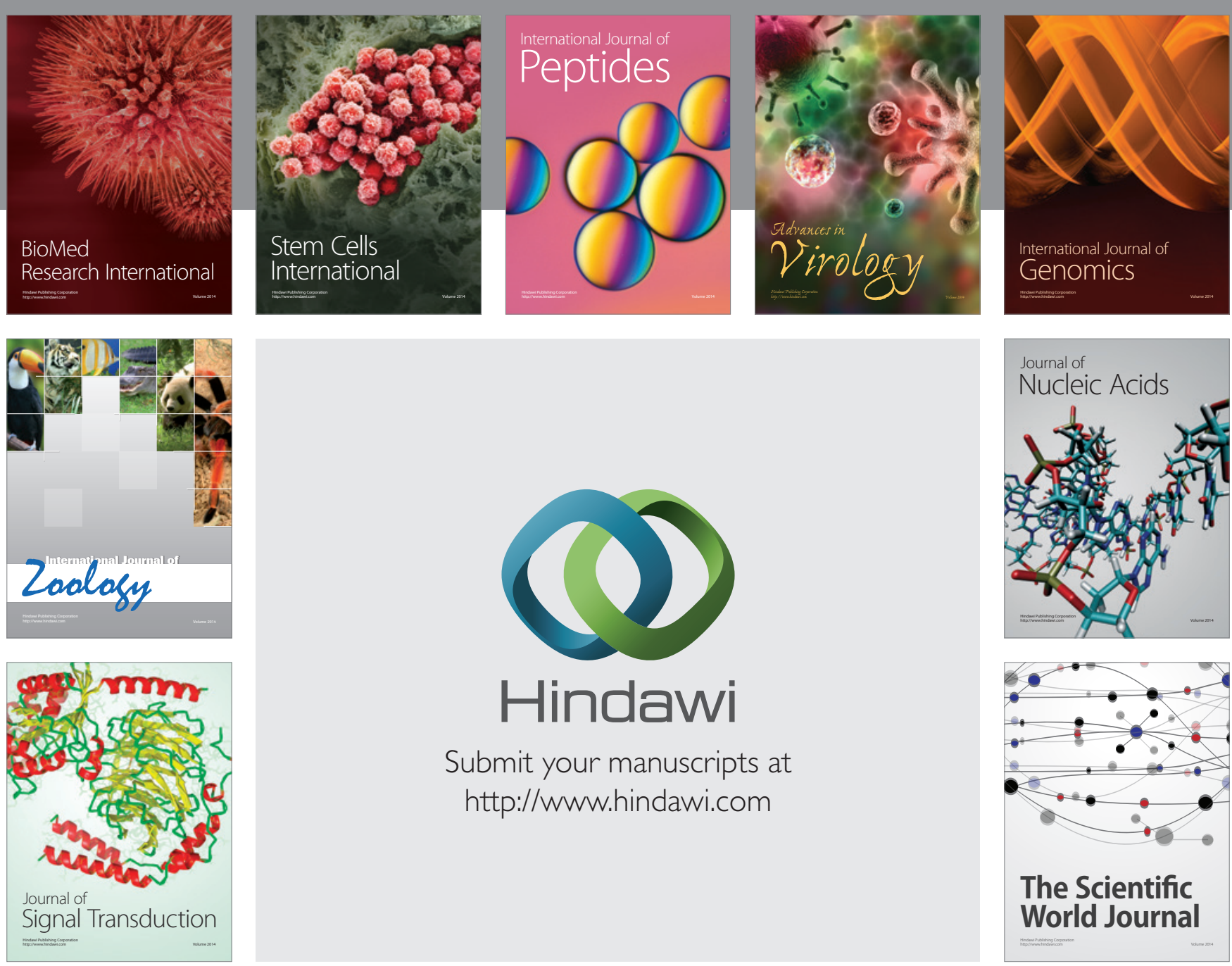

Submit your manuscripts at

http://www.hindawi.com
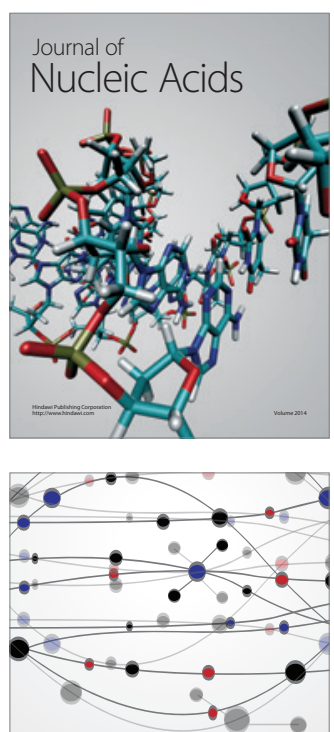

The Scientific World Journal
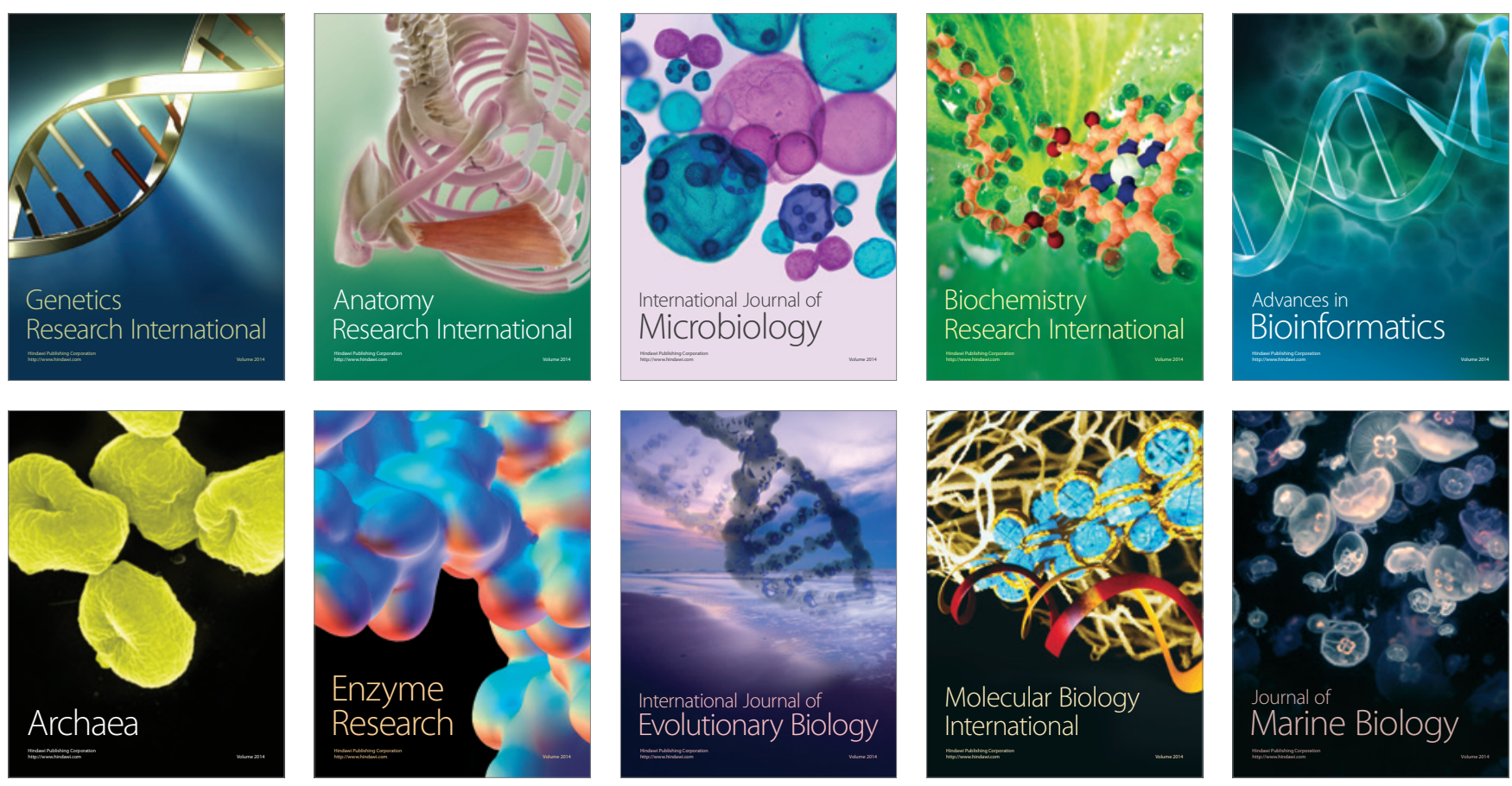